\title{
For Managing Editor Indigenous Way to Maternal Health Care within the Social System
}

\author{
Kiranjot Sidhu, Ramthirath Kaur and Kunwarjeet Pannu \\ Department of Extension Education, Punjab Agricultural University, Ludhiana 141 001, \\ Punjab, India \\ Telephone: 0161-5040979 (R); 09814098405 (M), E-mail: sidhs64@hotmail.com
}

KEYWORDS Awareness; health care; medicinal plants; dissemination

\begin{abstract}
The plant material and their products are being used for health care since ages. There is a vast array of knowledge among women regarding their use. But this knowledge is being lost due to non transfer to the future generations which is mainly due to more of stress being laid on instant medication. With fewer women using plants for maternal health, the future generation cannot observe there use pattern. In this context the present study was an attempt to understand the status of these medicinal plants in term of the awareness of rural women. The data collected from three districts of Punjab reveal that one third of the women were not aware that six of the twenty seven plants selected for the study were used for maternal health care. Three out of the remaining plants were known to less than fifty percent of the women. Some plants were known for their use but women were not aware of the purposes for which these were used during maternal health care, hence a significant difference was observed between the number of women aware of the use and purpose of use of these plant. All the women were aware of the plants like Chebulic myrobalan, Turmeric, Black pepper, Indian lilac, Dry ginger and Arecanut on both the parameters but some like Touch me not and Indian seena were known to less than ten per cent of the women. A comprehensive strategies need to be planned to for intra social dissemination of the information so that this rich heritage is not lost.
\end{abstract}

\section{INTRODUCTION}

Indigenous knowledge is valued and recognized as a rich natural resource in the custody of our society. Its use has been prevalent within the society in day to day living. The dynamic nature of indigenous knowledge has led to its survival through centuries. Some of the synonymous to the term are 'traditional knowledge' 'folk knowledge' and wisdom of the elders. Seeland (2000) has also referred to the local origin of the indigenous knowledge and its promotion by the community. In this context a pool of knowledge related to the use of available resources is developed by the community for a particular region. The knowledge is further enhanced by means of inter community contacts and availability of non- local resources.

Indigenous knowledge span the entire range of human experiences and in this context a vast array of knowledge is available regarding the use medicinal plants for health. Some earlier studies (Borthakur, 1992; Nagarajan, 2002 ) reported the use of medicinal plants for treating health disorders. But with increasing stress on quick remedies for health purposes, our ancient heritage is being lost. The awareness, knowledge and usage of this knowledge has diluted over a passage of time although they are effective today as they were thousands of years ago. The use of this knowledge is necessary as it is not only socially desirable but is economically affordable, sustainable and involves minimum risks and procedures. The present study was an attempt to generate data on the awareness pattern of rural women regarding some selected plants as reported by Roy (2001) in the Technical Bulletin 'Maternal Health-Data Bank on Pre and Post Delivery Care'. under the All India Coordinated Research Project to plan dissemination strategies for transfer of this knowledge within the family and social system and also to provide outside support. This can help to rejuvenate the indigenous knowledge of rural women regarding the use of medicinal plants for maternal health and lead to decrease in stress on medical services in view of the resource constraints of the country.

\section{Objectives}

1. To study the difference in awareness regarding use and purpose of use of selected medicinal plants for maternal health care.

2. To suggest strategies for dissemination of 
knowledge on use of medicinal plants for maternal health care.

\section{METHODOLOGY}

Three districts of Punjab namely Bhatinda, Faridkot and Ferozpur were selected for data collection. These were represented by two blocks each which were further represented by two villages each. Twenty five households per village were randomly selected from the list of those households who had at least one female member between the age group of 25-45 years who had given birth to at least one child.. Thus three hundred respondents were selected.

Personal interviews were conducted to collect data using a structured interview schedule.

The following variables were selected for the study:

Awareness Regarding Use: The response was take on basis of the respondent being aware that the particular food material is used or not used for maternal health care.
Awareness Regarding Purpose of Use: The response was take on basis of the respondent being aware of the purpose of use of particular plant ( based upon the properties of the plant and their effectiveness ) during maternal health care

The data thus collected was analyzed using numbers and percentages to determine the distribution of respondents according to their response The ' $\mathrm{z}$ ' test was applied to make comparisons between the two responses of the respondents.

\section{FINDINGS}

The data on two aspects of awareness regarding twenty seven medicinal plants as shown in the table reveal that 100 per cent of the respondents were aware that Chebulic myrobalan, Turmeric, Black pepper, Indian lilac, Dry ginger, and Arecanut were used for maternal health care and were even aware of the purpose of use during maternal health care. The use of some of these plants has also been reported by Kaur (1999) in

Table 1: Comparison of awareness regarding the use and purpose of use

\begin{tabular}{|c|c|c|c|c|c|c|c|}
\hline \multicolumn{3}{|c|}{ Name of the plant/part/product } & \multicolumn{4}{|c|}{ Respondents Awareness regarding } & \multirow{3}{*}{$\begin{array}{c}\text { 'z' } \\
\text { value }\end{array}$} \\
\hline \multirow[t]{2}{*}{ English name } & \multirow{2}{*}{ Botanical name } & \multirow{2}{*}{ Common name } & \multicolumn{2}{|c|}{ Use } & \multicolumn{2}{|c|}{ Purpose of use } & \\
\hline & & & No. & $\%$ & No. & $\%$ & \\
\hline Black babool & Acacia nilotica & Babool & 135 & 45 & 107 & 35.67 & $2.33 *$ \\
\hline Indian jujube & Ziziphus mauritiana & Ber & 284 & 94.67 & 261 & 87 & $3.25 *$ \\
\hline Indian pennywort & Centella asiatica & Brahmibuti & 89 & 29.67 & 76 & 25.33 & $1.99 *$ \\
\hline Blankultthi & Cassia absus & Chasku & 271 & 90.33 & 269 & 89.67 & $0.27 \mathrm{NS}$ \\
\hline Thorn apple & Datura metal & Datura & 206 & 68.67 & 178 & 59.33 & $2.38 *$ \\
\hline Turmeric & Curcuma longa & Haldi & 300 & 100 & 300 & 100 & $0 \mathrm{NS}$ \\
\hline Chebulic myrobalan & Terminalia chebula & Harad & 300 & 100 & 300 & 97.33 & $0 \mathrm{NS}$ \\
\hline Asafoetida & Ferula asafoetida & Hing & 286 & 95.33 & 269 & 89.67 & $2.63 *$ \\
\hline Indian birth wort & Aristolochia indica & Ishvarmul & 29 & 9.67 & 29 & 9.67 & $0 \mathrm{NS}$ \\
\hline Barley & Hordeum vulgare & Jaun & 271 & 90.33 & 249 & 83 & $2.64 *$ \\
\hline Kalimusli & Curculigo orchioides & Kalimusli & 231 & 77 & 216 & 72 & $1.40 \mathrm{NS}$ \\
\hline Black pepper & Piper nigrum & Kali Mirch & 300 & 100 & 300 & 100 & $0 \mathrm{NS}$ \\
\hline Kulfa & Thichodesma indicum & Kallributi & 102 & 34 & 96 & 32 & $0.52 \mathrm{NS}$ \\
\hline Kasni & Cichorium intybus & Kashni & 159 & 53 & 141 & 47 & $1.47 \mathrm{NS}$ \\
\hline Saffron & Crocus sativus & Kesar & 290 & 73 & 202 & 67.33 & $1.95 \mathrm{NS}$ \\
\hline Kehu & Costus specious & Keu & 49 & 16.33 & 37 & 12.33 & $1.40 \mathrm{NS}$ \\
\hline Poppy seeds & Vetiveria zizanioides & Khaskhas & 300 & 100 & 283 & 94.33 & $4.18 *$ \\
\hline Touch-me-not & Mimosa pudica & Lajjvanti & 6 & 2 & 6 & 2 & $0 \mathrm{NS}$ \\
\hline Garlic & Allium sativum & Lassan & 239 & 79.67 & 201 & 67 & $3.51 *$ \\
\hline Chunga & Sympolcus cochinchinensis & Lodh/chung & 285 & 95 & 284 & 94.67 & $0.18 \mathrm{NS}$ \\
\hline Indian lilac & Azadirachta indica & Neem & 300 & 100 & 300 & 100 & $0 \mathrm{NS}$ \\
\hline Wild asparagus & Asparagus racemosus & Sattowar & 143 & 47.67 & 122 & 40.67 & $1.73 \mathrm{NS}$ \\
\hline Indian senna & Cassia angustifolia & Senna & 23 & 7.67 & 20 & 6.67 & $0.47 \mathrm{NS}$ \\
\hline Dry ginger & Zingiber officinale & Sundh & 300 & 100 & 300 & 100 & $0 \mathrm{NS}$ \\
\hline Arecanut & Areca catechu & Supari & 300 & 100 & 300 & 100 & $0 \mathrm{NS}$ \\
\hline Bay leaves & Cinnamomum tamala & Tejpata & 94 & 31.33 & 84 & 28 & $0.89 \mathrm{NS}$ \\
\hline Cumin & Cuminum cyminum & Zeera & 292 & 97.33 & 287 & 95.67 & $1.11 \mathrm{NS}$ \\
\hline
\end{tabular}


her study on indigenous homestead practices.. Similarly no significant difference in awareness regarding use and purpose of use was observed in case of Blankultthi, Kali Musli, Saffron, Garlic, Lodh and Cumin seeds regarding which a very high percentage reported awareness on both accounts. The results clearly indicate that women are aware of the use of these medicinal plants for maternal health care. This can be attributed to their use by the elders which had been observed by them and subsequently they are also aware of their use for maternal health care. The easy availability of these plants can also be one of the reason for all the respondents being aware of their use.

A significant percentage was aware that Kasni $(53.00 \%)$, Wild asparagus $(47.67 \%$,) Kulfa $(34.00 \%)$, were used for maternal health care and most of them were aware of the purpose of use of these medicinal plants. No significant difference was observed in the distribution of respondents on both the counts for Kasni and Kulfa.

Contrary to this, a high percentage of respondents were aware of the use of Indian jujubee, Asafoetida, Barley, and Poppy seeds ( Between 100 and 90.00 percent ) but lesser percentage were aware of the purposes for which these were used, hence a significant difference in number of respondents in both the categories was observed. Significant difference in number was even observed for Black Babool and Thorn apple regarding which the percentage decreased from 45.00 to 35.67 per cent and 68.67 to 59.33 per cent respectively. Lack of awareness regarding the purpose of use might be the lack of knowledge on part of the elders or dissemination of knowledge within the family system.

Some commonly available plants like Indian pennywort, Indian birth wort, Kehu, Touch- menot, Indian seena and Bay leaves were known to very few respondents for their use for maternal health care hence very low percentage was aware of purposes of their use.

The data is an indication towards a need to make women aware about the use of some of the plants and the purpose of their use for maternal health care. Strategies need to be planned to make to women especially the younger generation understand the use of these plants so that these plants can be effectively used for maternal health care. This can help women to take care of her health during this crucial stage.

\section{STRATEGIES}

- The older generation needs to be motivated to pass the indigenous knowledge to the younger generation. This can be made possible by making the older generation aware of the importance of this effective information. Motivating them to disseminate this knowledge in the interest of the health of their future generation can help to create an impact.

- The present generation being more literate and living in a technologically advanced age tends to accept information that is available from modern sources of information. In this context it is the responsibility of the scientist and the extension functionaries to use mass media and personal approach to motivate the younger generate to practice the use of these highly effective plants for maternal health care. This information should be disseminated on scientific basis.

Scientific and social validation of indigenous knowledge can help to provide both scientific and social sanction and improve the chances of use of alternate sources of medicine among the generations to come.

\section{REFERENCES}

Borthakur, S.K. 1992. "Native phytotherapy for child and women diseases in north-eastern India." Fitoterapia, 63: 483-88.

Kaur, T. 1999. Scientific Validation of Indigenous Homestead Practices for Use by Rural Home Makers. Ph.D. Dissertation, Punjab Agricultural University, Ludhiana, India.

Nagarajan. 2002. "Making money from papaya. A mirage or reality?" Kisan World, 29: 23-27

Roy, S. 2001. Maternal Health-Data Bank on Pre and Post Delivery Care. Technical Bulletin. Published by ICAR, New Delhi.

Seeland, K. 2000. "What is indigenous knowledge and why does it matter today?", in Seeland Kaus and Fraz Schmithusen (eds.), Man in the Forest. New Delhi: D K. Printworld. 